\title{
Employment Intensity of Agricultural Growth in Nigeria
}

\author{
Adetunji Adeniyi, PhD \\ Tunji Adeniyi and Associates Limited, Lagos, Nigeria
}

\begin{abstract}
At over 50 per cent employment contribution, agriculture will continue to provide the bulk of employment in Nigeria for some time to come. It, therefore, becomes imperative to determine the employment intensity of agricultural growth with a view to advancing policies that will help to tame the unemployment problem. Time series secondary data covering 1981 to 2014 on the rebased Gross Domestic Product (GDP) and sectoral Gross Value Added (GVA) at 2010 constant basic prices, employment, wage rate, inflation rate and interest rate were collected from the National Bureau of Statistics and the Central Bank of Nigeria on the agricultural sector. The variables were collated and summarised into a table of data. The unit root test was carried out to test for stationarity of variables. Sectoral employment elasticities of growth were measured using Vector Error Correction Model (VECM) regression. Data was analysed using descriptive statistics and VECM at $\alpha_{0.05}$. Agriculture sectoral elasticity of employment was -0.13 , indicating that output growth in the sector, during the period, was achieved through productivity increases rather than the employment of more persons. Agricultural sectoral employment depended on GVA growth (agriculture $\beta=-0.13$; wage rate $(\beta=-0.023)$, interest rate $(\beta=$ $-0.011)$, inflation rate $(\beta=-0.002)$, and the inter-temporal $(\mathrm{t}-\mathrm{x})$ relationships. Employment in agriculture depended on previous year's wage rate $(\beta=-0.023)$ in agriculture and previous year's agricultural output $(\beta=-$ 0.13 ). Previous two years' employment in agriculture (agriculture $t_{-2} ; \beta=-1.94$ ) previous year's agricultural output (GVA agriculture $e_{-1} ; \beta=-0.13$ ) and previous year's wage rate (wage rate $t_{t-1} ;=-0.023$ ) limit current year's agricultural employment. Gross Value Added growth affected agricultural employment negatively in the period under review. Wage, inflation, and interest rates reduced employment.
\end{abstract}

Keywords: Economic growth, Employment elasticity, Gross Value Added, Agricultural Sector.

DOI: $10.7176 /$ JPID/60-03

Publication date:July $31^{\text {st }} 2021$

\section{Introduction}

Nigeria has continued to experience very high, rising and seemingly intractable levels of unemployment. Economists have postulated in literature that economic growth generates employment. It is against this backdrop that it was expected that the growth regime of 1981 to 2014 should have helped to reduce unemployment by generating a more than commensurate employment (Adeniyi, 2021).

Economic literature, however, acknowledges the advent of "jobless growth" whereby unemployment coexists with economic growth (Adeniyi, 2021).

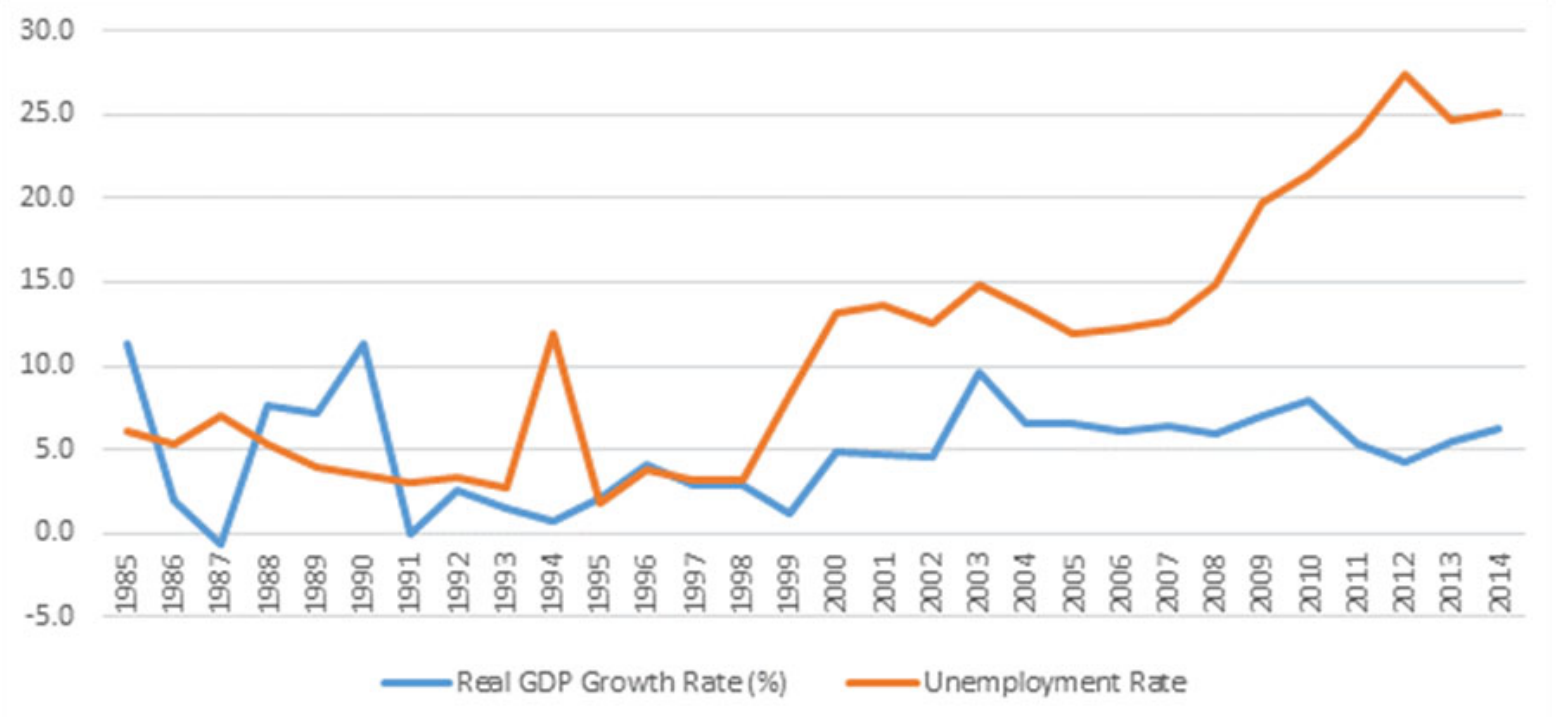

Source: Author's analysis of data collected from the National Bureau of Statistics

Figure 1: Rising Unemployment Co-existing with Economic Growth

According to the National Bureau of Statistics (2015) the rate of unemployment was 8.2 per cent by the end of the second quarter of 2015, despite the growth performance of the preceding years. The situation, which has further deteriorated due to subsequent economic decline, was recently accentuated by the outbreak of the 
COVID-19 pandemic, as unemployment rose to a record high of 27 per cent by the second quarter of 2020 (FGN, 2017; FGN, 2020; and, NBS, 2020).

Although, petroleum constitutes the major export product of Nigeria, accounting for about 95 per cent of government's external revenue, the Nigerian economy is still largely agrarian, accounting for more than 50 per cent employment (Adeniyi, 2019). If Agriculture is still to be expected to continue to provide the bulk of employment in the economy, then policy makers should be interested in the job creating capacity of the sector. The pertinent research question then is, what is the job absorptive capacity of the sector? Consequently, this study sets out to investigate the employment intensity of output growth in the agricultural sector?

\section{Literature Review}

Agriculture is the lead contributor to employment in Nigeria, accounting for more than 50\% of employment. According to Adeniyi, 2019, The contribution of agriculture to employment reduced from $68.3 \%$ in 1981 to $53.5 \%$ in 2014 , while that of non-agriculture increased from $31.7 \%$ to $46.5 \%$ for the same period. However, agriculture still employed the greater number, contributing 31,241,000 of the aggregate employment of $58,369,000$ in 2014. There is an increasing marginal shift from the Agricultural sector in both absolute figures and the proportion of people working in the sector. Although, overall employment in Manufacturing, just as in Agriculture, also fell significantly between 2005 and 2014, Agriculture consistently had the largest negative contribution to the change in employment rate in Nigeria between 2005 and 2014. During the period, only Mining and Services sectors registered absolute employment growth. Employment contribution, however, shrank in all sectors, except in the Services sector, where GDP contributions also more than doubled (Ajakaiye et al, 2016). According to Adeniyi (2019) employment is transitioning from production in the real sectors of Agriculture and Manufacturing to the Services sectors in Administration and Social Services, and Trade and Services sectors.

\section{Theoretical framework}

The national output of an economy, and by extension, any sector of the economy, is produced by combining labour input (demand for labor) with other factors of production in that economy or sector. The demand function for labor can be derived by assuming a constant elasticity of substitution (CES) production function and solving the marginal product of labor (MPL) equation for the labor input variable (Mkhize, 2015, and Adeniyi, 2019) as follows: -

$\mathrm{GVA}_{\mathrm{t}}=\mathrm{A}\left\{\alpha \mathrm{K}^{-\rho}+(1-\alpha) \mathrm{E}^{-\rho}\right\}^{-\eta /-\rho}$

where, $\mathrm{iEP}_{\mathrm{S}} \mathrm{GVA}=$ Gross Value Added (sectoral output)

$\mathrm{K}_{\mathrm{t}}=$ Capital (input) in year $\mathrm{t} ; \mathrm{E}_{\mathrm{t}}=$ Employment/labor (input) in year $\mathrm{t}$.

$\mathrm{A}=$ Efficiency parameter; $\mathrm{A}>0$

$\eta=$ Returns to scale parameter; $\eta>0$

$\alpha=$ Distribution parameter; $0<\alpha<1$

$\rho=$ Extent of substitution (between $\mathrm{K}$ and E) parameter, $\rho>-1$, and related to elasticity of substitution; $\sigma=1 /$

$1+\rho$

The derivative of labor (i.e. marginal product of labor $\left(\mathrm{MP}_{\mathrm{L}}\right)$ ) from Equation (1) can be written as:

$\mathrm{dGVA} / \mathrm{dE}=\eta(1-\alpha) / \mathrm{A}^{\rho / \eta} \cdot \mathrm{GVA}^{(1+\rho) / \eta} / \mathrm{E}^{\rho+1}$

The above $\mathrm{MP}_{\mathrm{L}}$ expression is solved for the $\mathrm{E}_{\mathrm{t}}$ input variable in order to derive the empirical labor (employment) demand function:

$\eta(1-\alpha) / A^{\rho / \eta} \cdot$ GVA $^{(1+\rho) / \eta}=\mathrm{E}_{\mathrm{t}}{ }^{\rho+1}$

[9]

$$
\begin{aligned}
& {\left[\eta(1-\alpha) / A^{\rho / \eta} \cdot \text { GVA }^{(1+\rho) / \eta 1 / \rho+1}\right]=\mathrm{E}_{\mathrm{t}}} \\
& \mathrm{E}_{\mathrm{t}}=\left[\eta(1-\alpha) / \mathrm{A}^{\rho / \eta} . \mathrm{GVA}{ }^{(1+\rho) / \eta}\right]^{1 / \rho+1} \\
& =\left[\eta(1-\alpha) / A^{\rho / \eta}\right]^{1 / \rho+1} \cdot \operatorname{GVA}{ }^{(1+\rho / \eta)(1 / \rho+1)}
\end{aligned}
$$


$\mathrm{E}_{\mathrm{t}}=\beta_{0} \mathrm{GVA}^{\beta 1}$

where,

$\beta_{0}=\left[\eta(1-\alpha) / A^{\rho / \eta}\right]^{1 / \rho+1}$

$\beta_{1}=(1+\rho / \eta)(1 / \rho+1)$

$\beta_{1}=1+\rho / \eta \cdot \sigma$

$\sigma$ (elasticity of substitution) $=1 / \rho+1$ ssep However, if we log-transform Equation (3) above, we obtain the following employment function:

$\ln \mathrm{E}_{\mathrm{t}}=\ln \beta_{0}+\beta_{1} \ln \mathrm{GVA}_{\mathrm{t}}^{\mathrm{CEEP}=}=\beta_{0}+\beta_{1} \ln \mathrm{GVA}_{\mathrm{t}}+\ldots \beta_{\mathrm{n}} \ln \mathrm{X}_{\mathrm{nt}}+\varepsilon_{\mathrm{t}}$

\section{Methodology}

The study examined the job absorptive capacity of the agricultural sector of the Nigerian economy. The employment intensity of agricultural gross value added growth between 1981 and 2014 was estimated. The secondary data used for the study were collected from the Central Bank of Nigeria (CBN), and the National Bureau of Statistics (NBS).

The variables collected, collated, analysed and presented were the figures of agriculture sectoral gross value added, agriculture sectoral employment, minimum wage rates, weighted average prime lending rates and inflation rates from 1981 to 2014. Similar data were collected for the non-agricultural sectors. Estimation methodology of elasticity of employment, in deference to Ajilore and Yinusa (2011); Mkhize (2015); and, Adeniyi (2019) was used to analyse the data. Specifically, we used the Vector Error Correction Model (VECM).

In order to estimate the sectoral employment elasticity of the agricultural sector of the economy and the elasticity of employment with respect to wage rate, inflation and user cost of capital in the economy during the period under review, a double-log linear regression equation was constructed for the parameters as follows:

$\ln L_{t}=\beta_{0}-\beta_{1} \ln W_{t}+\beta_{2} \ln r_{t}+\beta_{3} \ln G V A_{t}+\beta_{4} \ln \pi_{t}+T_{t}+\varepsilon_{t}$

where, $\mathrm{t}=1, \ldots, \mathrm{n}$ years. The dependent variable, $L_{t}$, represents aggregate employment (formal and informal, public and private) in thousands of persons in the specific economic sectors, in year $t$.

The exogenous variables are:

$\mathrm{W}=$ minimum wage rate in time $\mathrm{t}$, measured in thousand Naira.

$\stackrel{t}{r}=$ is the user cost of capital in time $\mathrm{t}$, represented by the weighted average prime lending rate in the economy.

$t$

$\pi=$ inflation rate in time $\mathrm{t}$.

$\stackrel{\mathrm{t}}{\mathrm{GVA}}=$ agriculture sectoral GVA in constant 2010 basic prices.

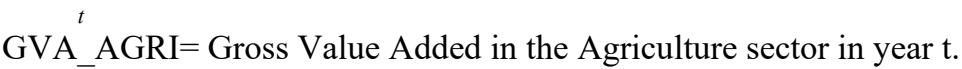

TIME $(\mathrm{T})=$ yearly time trend variable, where $\mathrm{t}=1$ is year ended December, 1981 and

$\mathrm{t}=34$ is year ended December, 2014.

$\varepsilon=$ error term.

$\mathrm{t}$

From the model, the equation to analyse is: -

EMP_AGRIC $=\mathrm{f}\left(\mathrm{GVA} \_\mathrm{AGRI} \mathrm{t}_{\mathrm{t}}, W_{t}, r_{t}, \pi_{t}\right)$

Where:

$$
\begin{aligned}
& W_{t}=\text { Minimum Wage Rate in year } \mathrm{t} \\
& r_{t}=\text { WAPLR in year } \mathrm{t} \\
& \pi_{t}=\text { inflation rate in year } \mathrm{t}
\end{aligned}
$$

The above model postulates that employment of persons in the agricultural sector, will vary with gross value added in agriculture, and macroeconomic variables of wage rate, interest rate, and inflation rate, and that employment decisions by economic units in the agricultural sector are a function of previous year's information.

\section{Description of the variables}

Gross Domestic Product (GDP): Gross Value Added (GVA) is the value of goods and services produced in a sector. It is the output of the sector less intermediate consumption in that sector. In this study, these variables were obtained from the Nigerian National Bureau of Statistics (NBS). Yearly agricultural GVA series at 2010 
constant basic prices were collected from NBS for the period 1981 to 2014 . The series, which were in billions of Naira, were produced after the GDP rebasing exercise of 2014 which used 2010 as the base year. (Adeniyi, 2021).

Time trend: In a time-series analysis, time is a variable as the other variables and the relationships among them changes or stabilises over time. The lagging approach employed in the analysis took care of the time trend in determining /explaining employment level in the economy (Adeniyi, 2021).

Wages: Wage series were not available from the National Bureau of Statistics and other relevant organisations. Furthermore, NBS has not produced the re-based GDP using expenditure approach as of the time of this study. The latter would have been decomposed to obtain the wage component.

Although there are various concepts of wages we adopted the minimum wage in the economy for the following reasons which outweigh its limited variability since it does not change annually: It is more relevant to policy making; more determinable with exactitude; better known to everybody; more relevant to the economic strata where employment expansion is most desired, more relevant in determining the minimum financial welfare in the economy, etc. According to ILO (1970) the minimum wage represents the amount of compensation that an employer is required to pay wage earners for the work performed during a giving period, which cannot be reduced by collective agreement or by an individual contract. Minimum wage is, therefore, the lowest compensation that employers may legitimately pay to workers. This implies that it is the price floor below which a worker may not legally sell his labour services (Adeniyi, 2021).

Furthermore, recent debates among the three tiers of Government in Nigeria, the Labour Union, the Legislators, Non-Governmental Organisations, and Social Commentators on minimum wage did not only support this choice but seems to have heavy impact on the ethnic - or geo - political organisation, reorganisation and/or viability of the federating units of Nigeria (Eme and Ugwu, 2011; Ajimotokan and Obi, 2016; Buhari, 2016). It is more relevant in employment decision making particularly in the government sector that is very wage elastic, but expected to be employment intensive. For example, according to the Senate of the Federal Republic of Nigeria in its plenary of July 21,2016 , '27 states of the federation can no longer pay the salary of their workers.'

Other wage concepts are: average wages in the public sector, average wages in the private sector, average wages in the junior staff category and average salaries and emoluments of senior staff categories both in the public and private sectors (NECA, 2003; and, Adeniyi, 2021). For this study, minimum wage change history was obtained from NBS and from this; the minimum wage series was generated.

Interest rate: There are various concepts of the user cost of capital (Ajilore and Yinusa, 2011 Mkhize, 2015). This study used the Weighted Average Prime Lending Rate (WAPLR) of banks operating in the economy during the period, because it is more relevant considering that it affects every economic borrowing decision in the economy. It is subject to regular (weekly) professional determination and reviews at the Assets and Liability Management Committees (ALCOs) of all the banks operating in the economy. Besides, the determination of WAPLR also bears reference to the weighted average cost of generating loanable funds by lenders in the economy. Long-term lending, available only to prime bank customers, is consummated at around the Prime Lending Rate (CBN, 2015; and, Adeniyi, 2021).

Unemployment Rate: The data of unemployment rate was collected at the National Bureau of Statistics (NBS). Inflation Rates: Annual Inflation Rates data were also collected from the National Bureau of Statistics. GVA: Annual GVA for the agricultural sector were collected from the National Bureau of Statistics.

\section{Unit Root Test}

Time series data are most useful when they do not contain noise or unit root problems. However, frequently associated with time series data is the problem of noise. Consequently, it is necessary to test for and remove unit roots when and if they exist in any series. If they do, the noise must first be removed before proceeding with analysis in other that the results are not spurious, in other words, so that we can rely on the results for interpretation.

When there is no unit root or the noise has been removed, the series is said to be stationary. Several tests of stationarity have been developed to examine whether a series is stationary or non-stationary. If the series under analysis is stationary at level, this implies that the series contains no noise. Therefore, the series is said to be $\mathrm{I}(0)$. However, if the series being analysed is non-stationary in its level form, but stationary in the first difference form, then, it is said to be integrated of order 1 or I(1). Most time series can be classified as being integrated of order $d, \mathrm{I}(d)$. This means that the series must be differenced $d$ times to become stationary. The most common test of the stationarity of a time series is the Augmented Dickey-Fuller (ADF) test proposed by Engle and Granger in 1987 as follows (Adeniyi, 2021):

$\Delta \boldsymbol{Y}_{\boldsymbol{t}}=\boldsymbol{\beta}_{1}+\boldsymbol{\beta}_{2_{t}}+\boldsymbol{\delta} \boldsymbol{Y}_{t-1}+\sum_{i=1}^{m} \alpha_{i} \Delta Y_{t-i}+\varepsilon_{t}$ 
where $Y$ is the relevant time series, $t$ is time trend, $\varepsilon$ a white noise error term ; where

$$
\Delta Y_{t-1}=\left(Y_{t-1}^{t}-Y_{t-2}\right), \Delta Y_{t-2}=\left(Y_{t-2}-Y_{t-3}\right)
$$

The hypothesis of the ADF test will be specified as follows:

Null hypothesis: Ho: $\beta=0$

Alternative hypothesis: $\mathrm{H}: \beta<0$

If the null hypothesis is not rejected, then the series is non-stationary, but if it is rejected, it means the series is stationary or $\mathrm{I}(0)$. A time series is stationary when the process by which the data is generated is the same over time. That is, the series' mean, variance and covariance with lagged values of itself should not change with time. (Hansen and King, 1996; Mkhize, 2015; and, Adeniyi, 2019). According to Mkhize, (2015) ADF test tends to over-reject the null hypothesis when using too few lags and to reduce the degrees of freedom when there are too many lags. Song and Witt (2000) in their study of tourism demand modelling and forecasting, justified the importance of appropriate lag length for time series data. In determining the appropriate lag length for the ADF test in the study, Schwarz Information Criterion was used.

\section{Cointegration Test}

According to Stock and Watson (2017) when variables individually non-stationary are co-integrated, two (or more) variables may have common underlying stochastic trends along which they move together on a nonstationary path. For simple instances of few variables and one co-integrating relationship, an error-correction model (ECM) is the appropriate econometric specification. In this model, the equation is differenced and an error-correction term estimating the previous period's ( $\mathrm{t}-1)$ deviation from long-run equilibrium is included.

The most common tests to investigate the number of common trends among the series in a VAR/VEC were developed and proposed by Johansen (1995). The approach is very similar to testing for unit roots in the polynomial representing an Auto Regression (AR) process. If we have $n$ I (1) variables that are modelled jointly in a dynamic system, there can be up to $n-1$ co-integrating relationships linking them. Stock and Watson (2017) thought of each co-integrating relationship as a common trend interconnecting some or all the series in the system. The co-integrating rank of the system is the number of such common trends, or the number of cointegrating relationships (Adeniyi, 2021).

To select the co-integrating rank $r$, a sequence of tests was performed. First, the null hypothesis of $r=0$ against $r \geq 1$ to investigate if there is at least one co-integrating relationship was tested. If and when $r=0$ is not rejected, then it was concluded that there were no common trends among the series, in which case, a VEC model is not needed. VAR is then simply used in the differences of the series.

If $r=0$ is rejected at the initial stage, then at least some of the series are co-integrated. Then, the number of co-integrating relationships is determined. The second step is to test the null hypothesis that $r \leq 1$ against $r \geq 2$. If the hypothesis of no more than one common trend is not rejected, then we estimate a VEC system with one cointegrating relationship.

If the hypothesis that $r \leq 1$ is rejected, then the hypothesis $r \leq 2$ against $r \geq 3$ is tested, and so on. $r$ is chosen to be the smallest value at which the null hypothesis that there are no additional co-integrating relationships is not rejected.

Johansen proposed many relevant tests that can be employed at each stage. The most common is the trace statistic, which was used in this study. The Stata command vecrank prints the trace statistic or, alternatively, the maximum-eigenvalue statistic.

\section{Vector Error Correction Model}

Vector error correction model (VECM) is the regression that takes into consideration the correction of the noise/unit root in the model as well as estimating the part of the noise that is being removed at each short run. (Stock and Watson, 2017). The software used for the regression analysis was Stata.

\section{A priori expectations}

The signs expected for the coefficients in the model are as follows:

W: negative. If and when the percentage change in nominal wages increases, it reduces employers effective $t$

demand for labour, given a constant budget constraint and vice-versa. (Dokpe 2001; Soto 2009; Baah-Boateng, 2013; and, Adeniyi, 2021).

$\mathbf{r}$ : positive or negative. If the interest rate increases, the demand by employers for capital decreases and the demand for consumer goods and services also decreases. The reduced demand for capital (that would become relatively more expensive) will reduce labour productivity and the depressed demand for consumer goods and 
services will decrease the derived demand for labour, vice versa. In these situations, employment would move in opposite directions to long term interest rates. However, in some industries capital may be a substitute for labour. In that wise, an increase in long term interest rates may depress the demand for capital and enhance the demand for labour, the substitute, vice versa. Consequently, long term interest rates would be a positive correlate of employment. (Malunda, 2012; Nangale, 2012; Baah-Boateng, 2013; Mkhize, 2015; and, Adeniyi, 2021).

$\pi$ : positive or negative. The effect of inflation rate is expected to either be positive or negative. When and if the rate of inflation increases, the marginal revenue products of labour increases. As a consequence, there is an increase in the demand for labour by employers. On the other hand, an increase in inflation rate may reduce consumer demand for goods and services, thereby depressing the derived demand for labour as a factor of production. (Mkhize, 2015).

GVA : positive. The growth of sectoral real GVA will lead to expanded derived demand for labour because employers will view real sector output growth as an indication of future expansion in demand for consumer final goods and services (Soto, 2009; Sodipe and Ogunrinola, 2011; Temitope, 2013; Mkhize, 2015; and, Adeniyi, 2021).

In order to make the model very useful for the analysis, equation (10) is log-linearised. The logarithmic functional form ensures that $\beta$ can be interpreted as elasticities (Koop, 2005 and Felipe and McCombie, 2015),

where $\beta$ is the elasticity of employment with respect to user cost of capital, while holding all other things constant ceteris paribus. In the same manner, also $\beta$ is the elasticity of employment with respect to output. It estimates the proportional change in the number of labour employed for a proportional change in sectoral GVA, holding other factors constant, ceteris paribus. Consequently, a positive elasticity coefficient of 0.25 , for example, indicates that a percentage increase in GVA is associated with a quarter of a percentage increase in the number of people employed. The employment elasticity coefficients that will be calculated from the equation above imply that employment is a direct correlate of output (Soto, 2009; Sodipe and Ogunrinola, 2011; Temitope, 2013; and, Adeniyi, 2021). Consequently, the elasticity coefficients estimated for individual economic sectors are suggestive of the correlation between the number of persons employed and gross value added.

\section{Findings and discussions}

Table 1 below presents the the result of the VECM estimation of equation 6. Column two of the table contains the estimated regression coefficients with respect to the variables in the first column. These coefficients also represent the elasticity of employment with respect to the respective variables. Thus, the elasticity of employment with respect to agricultural GVA is -0.02 , but it is not significant at $95 \%$ level of confidence. In the same manner, the estimated elasticities of employment with respect to wage rate, inflation rate and interest rate, respectively, are: $-0.00,-0.01$, and -0.01 , respectively, and the coefficients are, also, not significant at $95 \%$ confidence level.

Although, we may not be able to rely on these results for policy, because the coefficients are not significant, the interpretation of the result for agricultural GVA is that a one per cent change in agricultural GVA will lead to 0.02 per cent change in agricultural employment in the opposite direction. Similarly, a one per cent change in wage rate, inflation rate and interest rate, respectively, will lead to -0.00 per cent, -0.01 per cent, and -0.01 per cent change in agricultural employment in the opposite direction. 
Table 1: VECM estimation of employment intensity of agriculture sector in Nigeria.

$\mathrm{EMP} \_\mathrm{AGRIC}=\mathrm{f}\left(\mathrm{GVA} \_\mathrm{AGRI} \mathrm{I}_{t}, W_{t}, r_{t}, \pi_{t}\right)$

Vector error-correction model

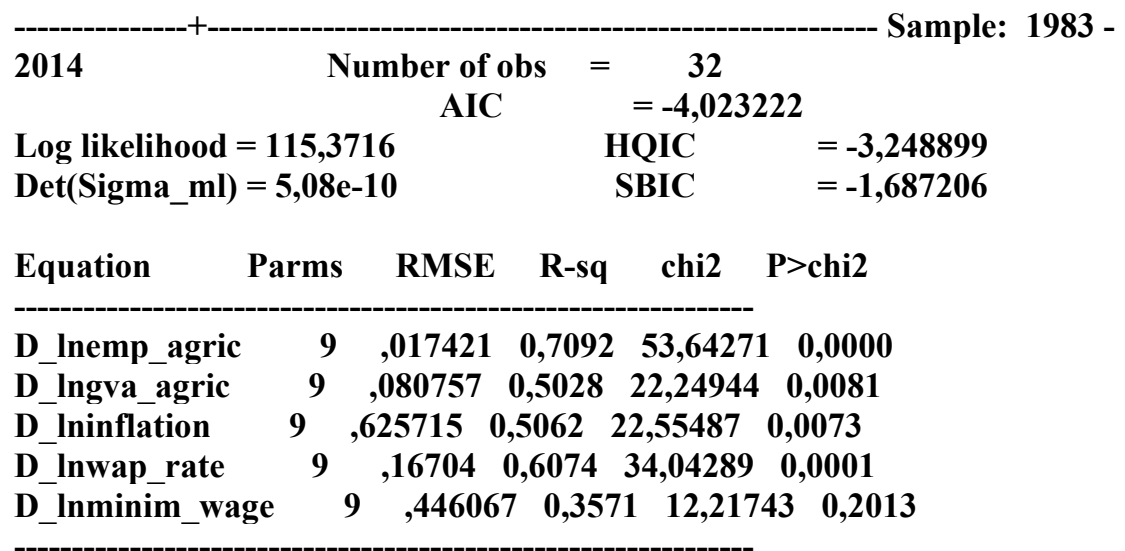

\begin{tabular}{|c|c|c|c|c|c|c|}
\hline | & Coef. $S$ & d. Err. & $\mathbf{z}$ & $\mathbf{P}>|\mathbf{z}|$ & {$[95 \%$ Con } & Interval \\
\hline \multicolumn{7}{|c|}{ D_Inemp_agric | } \\
\hline $\begin{array}{c}\overline{\text { L1. }} \\
\text { ce2 }\end{array}$ & $-0,19$ & $\mathbf{0 , 0 7}$ & $-2,68$ & $\mathbf{0 , 0 0 7}$ & $-0,32$ & $-0,05$ \\
\hline $\begin{array}{c}\text { L1. } \\
\mid \\
\text { ce3 } \mid\end{array}$ & $\mathbf{0 , 0 4}$ & $\mathbf{0 , 0 1}$ & 2,87 & 0,004 & $\mathbf{0 , 0 1}$ & 0,06 \\
\hline L1. & $\mathbf{0 , 0 1}$ & $\mathbf{0 , 0 1}$ & 1,60 & 0,109 & $-0,00$ & $\mathbf{0 , 0 2}$ \\
\hline \multicolumn{7}{|c|}{ Inemp_agric | } \\
\hline LD. $\mid$ & 0,11 & 0,19 & 0,56 & $\mathbf{0 , 5 7 3}$ & $-0,26$ & $\mathbf{0 , 4 7}$ \\
\hline \multicolumn{7}{|c|}{ Ingva_agric | } \\
\hline LD. & $-\mathbf{0 , 0 2}$ & 0,05 & $-0,34$ & 0,737 & $-0,10$ & $\mathbf{0 , 0 7}$ \\
\hline \multicolumn{7}{|l|}{ Ininflation | } \\
\hline LD. $\mid$ & $-0,01$ & $\mathbf{0 , 0 1}$ & $-1,09$ & $\mathbf{0 , 2 7 7}$ & $-0,02$ & $\mathbf{0 , 0 0}$ \\
\hline \multicolumn{7}{|c|}{ Inwap_rate | } \\
\hline L'D. & $-\mathbf{0 , 0 1}$ & $\mathbf{0 , 0 2}$ & $-0,79$ & 0,429 & $-0,05$ & $\mathbf{0 , 0 2}$ \\
\hline \multicolumn{7}{|c|}{ Inminim_wage | } \\
\hline $\begin{array}{c}\text { LD. } \\
\mid\end{array}$ & $-\mathbf{0 , 0 0}$ & $\mathbf{0 , 0 1}$ & $-0,13$ & $\mathbf{0 , 8 9 8}$ & $-0,02$ & $\mathbf{0 , 0 1}$ \\
\hline _cons | & $\mathbf{0 , 0 3}$ & $\mathbf{0 , 0 1}$ & 4,06 & $\mathbf{0 , 0 0 0}$ & $\mathbf{0 , 0 2}$ & 0,04 \\
\hline
\end{tabular}

Source: Author's Analysis of Data collected from the National Bureau of Statistics

Since agriculture employs and will continue to employ the bulk of the Nigerians for some time to come, we should be able to design policies on agricultural employment. Furthermore, the economy consists of other sectors with which agriculture co-exists and establishes various dynamic linkages, which if estimated, may help explain the job absorptive capacity of the agricultural sector (Adeniyi, 2019). In order to assist in further analysis, a system of six plausible scenarios were developed from a system of six simultaneous equations of employment from the series as follows: -

Scenario 1: Intot_empl $=\mathrm{f}\left(\operatorname{lnemp\_ agric}, \operatorname{lnemp}\right.$ _non-agric, lngva_agric, lngva_nonagric.)

Scenario 2: $\operatorname{lntot} \_$empl $=\mathrm{f}\left(\operatorname{lnemp} \_\right.$agric lnemp_minin lnemp_manufac lnemp_const lnemp_admin lngva_agric 
lngva minin lngva manufac lngva const lngva admin)

Scenario 3: lntot_empl = f (lnemp_agric lnemp_mini lnemp_manufac lnemp_const lnemp_admin lninflation lnwap_rate lnminWage)

Scenario 4: lntot_empl = f (lngva_agric lngva_minin lngva_manufac lngva_const lngva_admin lninflation lnwap rate lnminimWage)

Scenario 5: lntot_empl = f (lngdp lninflation lnwap_rate, $\operatorname{lnminim} \_$wage $)$

Scenario 6: Inemp_agric $=\mathrm{f}\left(\operatorname{lnemp} \_\right.$minin lnemp_manufac lnemp_const lnemp_admin lngva_agric lngva_minin lngva_manufac lngva_const lngva_admin)..

The above equations (9) were then estimated using VECM, and the results presented in Table 2 below. Results in scenario 1 show that the noise will be removed at each short run in such a way that in the long-run there will be a stable relationship. More specifically, the error will be reduced by 2.07 each year. The table also shows that the current level of employment in agriculture is negatively influenced by the previous year's level of employment in the same sector (Agriculture), the level of GVA in Agriculture and minimum wage on one hand. On the other hand, it is positively and significantly influenced by previous year's level of employment in nonAgriculture and by GVA non-Agriculture. In addition, scenario 2 and 4 show that among the sectors only Manufacturing and Administration significantly influenced negatively and positively respectively the current level of employment. The GVA of all the sub-sectors have significant effect (either positive or negative) on the current level of employment.

The current level of employment in the Agricultural sector is negatively influenced significantly by the last two years' level of employment in the Agricultural sector.

\section{Table 2: Employment in agriculture sector}

\begin{tabular}{|c|c|c|c|c|c|c|}
\hline & Scenariol & Scenario2 & Scenario3 & Scenario4 & Scenario5 & Scenario6 \\
\hline & Coef. (z) & Coef.(z) & Coef.(z) & Coef.(z) & Coef.(z) & Coef.(z) \\
\hline $\mathrm{Ce} 1$ & $2.45(1.34)$ & $0.128(2.99)^{* * *}$ & $-3.135(-0.79)$ & $-1.252(-3.34)^{* * *}$ & - & $-0.0611(-0.39)$ \\
\hline $\mathrm{Ce} 2$ & $-2.07(-2.13) * *$ & $-0.114(-2.62)^{* * * *}$ & $3.328(1.11)$ & $-0.986(-3.72)^{* * *}$ & - & $0.009(0.33)$ \\
\hline $\mathrm{Ce} 3$ & $-.497(-0.65)$ & $0.275(2.95)^{* * *}$ & $-0.416(-1.26)$ & $2.133(3.56)^{* * *}$ & - & $0.141(0.43)$ \\
\hline $\mathrm{Ce} 4$ & & $-0.119(-3.08)^{* * *}$ & & - & - & \\
\hline Employment Agriculture(-1) & $0.11(0.08)$ & $-0.705(-2.26)^{* *}$ & $-2.678(-1.24)$ & - & - & - \\
\hline Employment Agriculture(-2) & $-1.94(-2.08)^{* *}$ & $0.156(0.36)$ & $-0.497(-0.49)$ & - & - & $-0.171(-0.3)$ \\
\hline Employment Mining(-1) & - & $-0.449(-1.22)$ & - & - & - & $-0.29(-0.73)$ \\
\hline Employment Mining(-2) & - & $-0.309(-0.74)$ & - & - & - & $-0.038(-0.06)$ \\
\hline Employment Manufacturing (-1) & - & $-0.112(-0.67)$ & - & - & - & $-0.734(-1.33)$ \\
\hline Employment Manufacturing (-2) & - & $-0.354(-1.97)^{* *}$ & - & - & - & $-0.006(-0.02)$ \\
\hline Employment Construction $(-1)$ & - & $0.081(0.17)$ & - & - & - & $-0.012(-0.03)$ \\
\hline Employment Construction(-2) & - & $-0.649(-1.54)$ & - & - & - & $-0.122(-0.16)$ \\
\hline Employment Admin(-1) & - & $-0.027(-0.07)$ & - & - & - & $0.074(0.12)$ \\
\hline Employment Admin $(-2)$ & - & $0.913(2.30)^{* *}$ & - & - & - & $-0.06(-0.56)$ \\
\hline Employment Trade & - & - & - & - & - & $0.051(0.62)$ \\
\hline Employment Non-agric(-1) & $-0.25(-0.35)$ & - & - & - & - & \\
\hline Employment Non-agric $(-2)$ & $1.15(2.23)^{* *}$ & - & - & - & - & - \\
\hline GVA Agriculture(-1) & $-0.13(-2.10)^{* *}$ & $-0.0653(-1.98)^{* *}$ & - & - & - & \\
\hline GVA Agriculture(-2) & $0.018(0.34)$ & $0.0356(0.96)$ & - & $1.18(3.75)^{* * *}$ & - & $-0.06(-0.56)$ \\
\hline GVA Mining(-1) & - & $0.115(1.98)^{* *}$ & $1.219(1.23)$ & $0.561(2.29)^{* *}$ & - & $0.051(0.62)$ \\
\hline GVA Mining(-2) & - & $0.126(3.54)^{* * * *}$ & $0.843(0.90)$ & $-0.184(-0.51)$ & - & $0.014(0.17)$ \\
\hline GVA Manufacturing (-1) & - & $-0.022(-0.6)$ & $0.089(0.09)$ & $-0.205(-0.8)$ & - & $0.107(1.26)$ \\
\hline GVA Manufacturing $(-2)$ & - & $-0.069(-1.91)^{*}$ & $-0.332(-0.55)$ & $-0.252(-0.56)$ & - & $-0.0005(-0.01)$ \\
\hline GVA Construction $(-1)$ & - & $-0.003(-0.10)$ & $-2.303(-0.94)$ & $-0.538(-2.82)^{* * *}$ & - & $-0.003(0.09)$ \\
\hline GVA Construction(-2) & - & $-0.14(-2.80)^{* * *}$ & $-1.589(-0.90)$ & $0.757(3.77) * * *$ & - & $-0.016(-0.18)$ \\
\hline GVA Admin $(-1)$ & - & $0.64(3.83)^{* * *}$ & $0.974(0.92)$ & $0.506(2.33) * *$ & - & $-0.023(-0.46)$ \\
\hline GVA Admin $(-2)$ & - & $0.48(4.31)^{* * *}$ & $1.492(1.34)$ & $-1.405(-2.61) * * *$ & - & $0.177(0.54)$ \\
\hline GVA Trade & - & 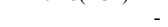 & - & $-2.669(-4.23) * * *$ & - & $0.259(0.9)$ \\
\hline GVA Non-agric(-1) & $0.085(0.70)$ & - & - & - & - & \\
\hline GVA Non-agric $(-2)$ & $0.39(2.59)^{* *}$ & - & - & - & - & - \\
\hline GDP & & - & & - & - & - \\
\hline Inflation Rate(-1) & $-0.002(-0.34)$ & - & $-0.008(-0.72)$ & - & - & - \\
\hline Inflation Rate(-2) & $0.008(1.21)$ & - & $-0.001(-0.18)$ & - & - & - \\
\hline WAPLR(Weighted Average Prime Lending Rate)(-1) & $-0.03(-1.56)$ & - & $-0.052(-1.25)$ & $-0.008(-0.42)$ & - & $-0.0008(-0.11)$ \\
\hline WAPLR(Weighted Average Prime Lending Rate)(-2) & $-0.011(-0.67)$ & - & $-0.037(-1.22)$ & $-0.0002(-0.01)$ & - & $0.006(0.83)$ \\
\hline Minimum wage $(-1)$ & $-0.023(-2.10)^{* *}$ & - & $-0.007(0.98)$ & $0.556(3.47)^{* * *}$ & - & - \\
\hline Minimum wage $(-2)$ & $-0.009(-1.06)$ & - & $-0.001(-0.11)$ & $0.147(1.51)$ & - & - \\
\hline Constant & $0.04(2.68)^{* * *}$ & $0.002(-0.13)$ & $0.009(0.44)$ & $-0.062(-1.38)$ & - & - \\
\hline
\end{tabular}

Source: Author's Analysis of Data collected from the National Bureau of Statistic

The intertemporal elasticity of employment is -1.94 , meaning that a one per cent change in the past two years' employment in the Agricultural sector results in 1.94 per cent change, in the opposite direction, in this year's level of employment in the Agricultural sector.

Similarly, the growth elasticity of employment with respect to Gross Value Added in the Agricultural sector is -0.13 , and lagged by one year. This means that a one per cent change in Gross Value Added in Agriculture in the previous year results into a change of 0.13 per cent in the opposite direction in the current level of employment in the Agricultural sector.

Furthermore, the elasticity of employment in the Agricultural sector with respect to the non-Agricultural Gross Value Added is 0.39 , positive and has a lag of 2 years. This means, a one per cent change in the level of Gross Value Added in the non-Agricultural sector in the prior 2 years is accompanied by a change, in the same direction, of 0.39 per cent in current year's employment in the Agricultural sector.

Another significant relationship is that between minimum wage and employment in the Agricultural sector, which has a coefficient of -0.023 and lagged by one year. This implies that a one per cent change in the 
minimum wage of the previous year is accompanied by a change, in the employment level, in the opposite direction, of 0.023 per cent.

\section{Conclusions}

When considered as a stand-alone sector, the estimates of employment intensity with respect to GVA, interest rates, wage rates, and inflation rates for the agricultural sector were not significant. However, when the employment function was considered and redefined with the non-agricultural sectors, as exist in real life, the estimates became significant and explained some of the real-life issues that have characterised agricultural production production in Nigeria. For example, it explains the inter-temporal linkages among agricultural production seasons which manifest as a vicious cycle of alternate high and low primary agricultural output. This is usually characterised by a high proportion of post-harvest wastes due to lack of processing and enduring storage facilities, and the lack of ready off-takers, usually aggravated by poor access roads that could facilitate evacuation to urban markets or household tables.

Furthermore, the results explain the inter-sectoral linkages and the inter-connectedness of agriculture to other sectors of the economy through value chains in the supply of primary produce and raw materials into agroprocessing, manufacturing and in food supply to household tables. It, also, explains inter-sectoral labour mobility, particularly, of unskilled labour to other sectors, such as artisanal mining (of solid minerals) transportation (using motor cycles, known in the local parlance as "Okada") and other informal trades and occupations prevalent in the rural areas. This is further aggravated by the seasonality of rain-fed agriculture that keeps the farmers underemployed or unemployed off-season.

\section{Recommendations}

In other to take advantage of the job absorptive capacity of the agricultural sector, policy makers should create and implement policies aimed at exploiting the inter-temporal linkages in agriculture and the inter-sectoral linkages with the other sectors of the economy, through well-developed and well-resourced value chains.

The development of well mapped-out agricultural value chains will make otherwise seasonal agricultural products available all-year-round in other forms through investment in storage, processing and preservation. This will create more jobs and even-out otherwise seasonal demand for farm labour. Similarly, investment in intersectoral activities like irrigation and smart agriculture infrastructure, and general manufacturing will facilitate increased and all-year-round demand for farm labour and create more jobs across the value chain. The lag represents the the length of the transmission mechanism in job creation between the sectors.

With regard to the negatively correlated interest rate, wage rate, and inflation rate, government should create appropriate agricultural investment climate through general macroeconomic stability, provision of agricultural production, processing and marketing infrastructure, and incentives, particularly for the youth and women, who both have little access to productive resources, despite constituting the bulk of the population, and of the unemployed. Access to interest-rate-friendly loans of appropriate tenors should, also, be provided.

\section{References}

Adeniyi, A. 2021. Designing a framework for employment-growth targeting in Nigeria. Journal of Asia Development. ISSN 2377 - 9594.

Adeniyi, A. 2019. Economic growth and employment nexus in Nigeria's agricultural and non-agricultural sectors (1981-2014). PhD Thesis in the Department of Agricultural Economics (in Press).

Ajakaiye, O. et al. 2016. Understanding the Relationship Between Growth and Employment in Nigeria. Africa Growth Initiatives at Bookings. Development Policy Research Unit, United Nations University, UNUWIDER. May.

Ajilore, T. and Yinusa, O. 2011. An Analysis of Employment Intensity of Sectoral Output Growth in Botswana. Southern Africa Business Renew, 15(2):26-42.

Ajimotokan. O. \& Obi. P. 2016. Government and NLC, set up technical committee on minimum wage and pump price of petrol. Back page, Thisday Newspaper, May 26.

Baah-Boateng, W.2013. "Determinants of Unemployment in Ghana," African Development Review, 21(4):385399, December, Wiley Publication.

Buhari, M. 2016. 27 States have difficulties paying salaries. Punch Newspapers, July 24.

Dopke, J. 2001. The Employment Intensity of Growth in Europe. Kieler Arbeitspapiere. No. 1021. Available at: http://hdl.handle.net/10419/17746.

Douglas, P. H. 1948. Are There Laws of Production? American Economic Review. March. 1-41.

Eme, O. I. and Ugwu, S. C. 2011. Governors and the new minimum wage act: implications for state-labour relations in Nigeria. Arabian Journal of Business and Management Review vol 1 No 3.

FGN (Federal Government of Nigeria). 2020. Bouncing Back: Nigeria Economic Sustainability Plan.

FGN (Federal Government of Nigeria). 2017. Economic recovery and growth plan, 2017-2020. Ministry of 
Budget and National Planning. February.

Felipe, J. and McCombie, J. S. L. 2015. Aggregate Production Function and the Measurement of Technical Change 'Not Even Wrong'. Edward Elgar Publishing Ltd. ISBN 978184064064255.

Hansen, P. and King, A. 1996. The determinants of health care expenditure: A co-integration approach. Journal of Health Economics Volume 15, Issue 1, February, Pages 127-137.

ILO. 1970. General Survey of the Reports of the Minimum Wage Fixing Convention. No. 131, and the Minimum Wage Fixing Recommendations No. 135. International Labour Conference, $103^{\text {rd }}$ Session, 2014. ILC.103/III/1B.

Johansen, Soren. 1995. Likelihood-Based Inference in Co-integrated Vector Autoregressive Models. Oxford: Clarendon Press.

Koop, G. 2005. Analysis of Economic Data, 2nd edition. John Wiley \& Sons.

Malunda, D. 2012. Employment Intensity of Non-Agricultural Growth in Rwanda: Analysing the Links between Growth, Employment and Productivity in Rwanda. Institute of Policy Analysis and Research. Rwanda.

Mkhize, N. 2015. The Sectoral Employment Intensity of Growth in South Africa: 2000:01 - 2012:04. School of Economic Sciences, University of South Africa. P.O. Box 392, Pretoria, 0003. South Africa.

Nangale, G. 2012. The Role of the State in Economic Development: Employment Challenges in Eastern Africa The case of Tanzania. A Country Paper Presentation at the Friedrich Ebert Stiftung (FES) Eastern African Conference on Employment Policies in Nairobi, Kenya. September 24 - 25.

National Centre for Economic Management and Administration (NCEMA) (a\&b). 2004. Understanding Structural Adjustment Programme in Nigeria. A Draft Report Submitted to Global Development Network. Presented at the Workshop on Understanding Reform, New Delhi, India. January 25-26.

NBS. 2020. Unemployment and Underemployment Report.

NBS. 2015. Nigerian Gross Domestic Product Report, Quarter Two. Issue 6.

NBS. 2015. Unemployment / Under-employment Watch.

Nigeria Employers' Consultative Association (NECA). 2003. Inter Industrial Survey.

Sodipe, O. A. and Ogunrinola, O. I. 2011. Employment and Economic Growth Nexus in Nigeria. International Journal of Business and Social Science, Vol. 2 No. 11.

Song, H. and Witt, S. F. 2000. Tourism demand modelling and forecasting: Modern econometric approaches. Oxford, Pergamon.

Soto, R. 2009. Dollarisation, Economic Growth and Employment. Economic Letters, 105(1):42-45.

Stock, J. H. and Watson, M. W. 2017. Introduction to Econometrics. Update. Third Edition. Pearson Education.

Temitope, L.A.L. (2013). Does Economic Growth Lead Employment in South Africa? Journal of Economics and Behavioural Studies, Vol. 5, No. 6, pp. 336-345. 